\title{
Typing of Australian methicillin-resistant Staphylococcus aureus strains by pulsed field gel electrophoresis
}

\author{
M.-Q. WEI and W. B. GRUBB* \\ School of Biomedical Sciences, Curtin University of Technology, GPO Box U1987, Perth 6102 \\ Western Australia
}

\begin{abstract}
Summary. Twenty-six clinical isolates of methicillin-resistant Staphylococcus aureus (MRSA) collected from six Australian hospitals by a National Staphylococcal Study Group were examined by analysis of restriction fragment length polymorphisms (RFLPs) of chromosomal DNA with pulsed field gel electrophoresis. Digestion with the restriction endonuclease SmaI produced 13-17 bands of 7-700 kb. The digestion patterns were easily distinguished and isolates could be classified into 17 groups based on their RFLPs. Isolates giving a pattern associated with one group were from four hospitals in four different states. In another group, the isolates responsible were from three hospitals in two states and in a further group, the isolates were derived from two hospitals in different states. The remaining groups comprised only one member each. The method has promise for typing and studying the epidemiology of MRSA.
\end{abstract}

\section{Introduction}

The isolation of methicillin-resistant Staphylococcus aureus (MRSA) in Australia was reported in $1962^{1}$ and although, between 1964 and 1967, the incidence of MRSA amongst $S$. aureus isolates was reported to be $5.7 \%^{2}$ they do not appear to have caused serious problems. ${ }^{3}$ However, the emergence of gentamicinresistant $\mathrm{MRSA}^{4}$ appears to have been associated with a resurgence of MRSA and by the early 1980s the epidemic spread of MRSA was being reported, ${ }^{5}$ and, in some cases, up to $50 \%$ of all $S$. aureus isolates were MRSA. ${ }^{5}$

The causes for this resurgence in resistant strains are not known. Possible reasons that have been advanced include antibiotic abuse, bad cross-infection control ${ }^{6}$ and the emergence of a new strain with a particular property. ${ }^{7,8}$ Although it has not been possible to ascribe any particular property to the isolates which would account for their success, plasmid analysis and the location of resistance determinants have shown that the more recent strains from eastern Australian hospitals (EA MRSA) ${ }^{8}$ are different from earlier isolates (classic MRSA) ${ }^{8}$ These results also indicated that, except for occasional differences in plasmid content, a particular strain had spread to the different Australian hospitals. ${ }^{8-11}$

Despite many attempts, no successful methods for typing the EA MRSA have emerged. Because most of the isolates are untypable with the standard inter-

Received 9 Sept. 1991 ; accepted 19 Nov. 1991.

* Correspondence should be sent to Professor W. B. Grubb. national phage typing set, phage typing has not been very successful even though supplementary phages have been useful. ${ }^{12}$ New molecular techniques are now available for studying total genomic differences between isolates. Chromosomal DNA can be cut with restriction enzymes and the resulting restriction fragment length polymorphisms (RFLPs) analysed by gel electrophoresis. High frequency cutting restriction enzymes have been used to compare MRSA ${ }^{13,14}$ but the large numbers of bands produced are difficult to compare and the use of low frequency cutting restriction enzymes produces fragments which cannot be resolved satisfactorily by conventional gel electrophoresis..$^{15}$ The development of pulsed field gel electrophoresis (PFGE) has enabled large fragments of DNA $(>9000 \mathrm{~kb})$ to be separated..$^{15}$ Variations of this technique are Contour-clamped Homogeneous Electric Field (CHEF) ${ }^{16}$ and Field Inversion Gel Electrophoresis (FIGE). ${ }^{17}$ These methods have been used primarily to analyse the genomes of eukaryotic organisms such as fungi and protozoa which are up to about 10 megabases in size. ${ }^{18,19}$ However, more recently, these methods have been used to study the chromosomes of bacteria. The cells have been lysed and cut with restriction enzymes in agarose blocks to prevent shearing of the DNA. ${ }^{20}$ Examples of the applications of these methods are the use of the CHEF to size and map the chromosomes of Escherichia coli $^{21}$ and Haemophilus influenzae, ${ }^{22}$ and of the FIGE to fingerprint Pseudomonas aeruginosa ${ }^{23}$ and staphylococci. ${ }^{24}$

The results of a National Staphylococcal Study Group (NSSG) in Australia have indicated that MRSA continue to be a problem in Australian 


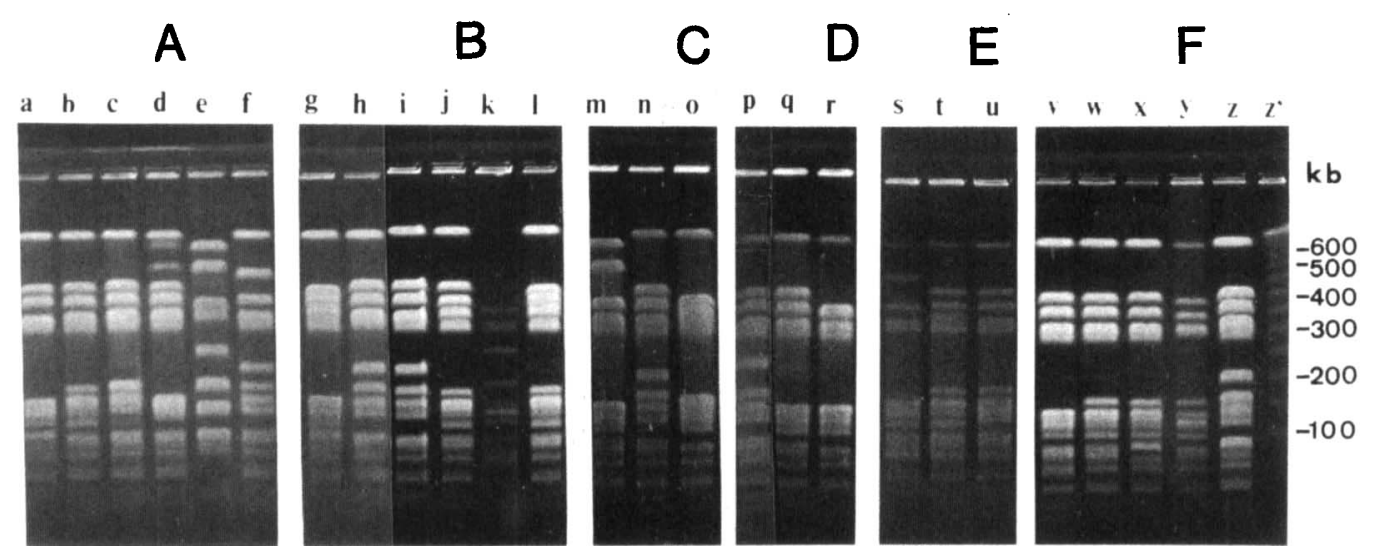

Fig. 1. DNA bands and banding patterns of chromosomes of MRSA digested with SmaI. Isolates from (A) Melb-2: lane a, V1202; b, V1204; c, V1207; d, V1210; e, V1212; f, V1218; (B) Melb-1: g, V2801; h, V2802; i, V2803; j, V2804; k, V2805; l, V2828; (C) Syd-1: m, V4621; n, V4624; o, V4636; (D) Adel: p, V7718; q, V7713; r, V7714;(E) Syd-2: s, V9082;t, V9083; u, V9085; (F) Bris: v, V5701; w, V5702; x, V5711; $\mathrm{y}, \mathrm{V} 5719 ; \mathbf{z}$, V5735; z', size control, phage $\lambda$ concatemers.

hospitals. ${ }^{25}$ This paper reports the application of restriction endonuclease digestion in the typing of genomic DNA in clinical isolates.

\section{Materials and methods}

\section{Strains of MRSA}

Twenty-six MRSA isolates collected from six hospitals around Australia by the $\mathrm{NSSG}^{25}$ were analysed. They were supplied by Ms Alison Vickery, Royal Prince Alfred Hospital Sydney, New South Wales (NSW). Isolates V4621, V4624 and V4636 were from one Sydney Hospital (Syd-1); V9082, V9083 and V9085 from another Sydney Hospital (Syd-2); V2801-5 and V2828 from a Melbourne, Victoria (VIC), Hospital (Melb-1); V1202, V1204, V1207, V1210, V1212 and V1218 from another Melbourne hospital (Melb-2); V5701, V5702, V5711, V5719 and V5735 from a Brisbane, Queensland (QLD), Hospital (Bris), and V7713, V7714 and V7718 from an Adelaide, South Australia (SA), hospital (Adel).

\section{Preparation of chromosomal DNA and CHEF electrophoresis}

These have been described previously. ${ }^{26}$ Briefly, MRSA were grown to late log phase, washed and resuspended in $50 \mathrm{~mm}$ EDTA buffer to a concentration of $c .6 \times 10^{5}$ cells $/ \mathrm{ml}$. The cells were then suspended in agarose $1 \%$ and lysed. Portions of the blocks were treated with Smal restriction enzyme and loaded on to an agarose $1 \%$ slab gel and electrophoresed at $120 \mathrm{~V}$ for $42 \mathrm{~h}$ at $9^{\circ} \mathrm{C}$ in Tris borate EDTA buffer in a CHEFDR II PFGE system (BioRad, USA) with mol. wt standards. The similarity of the RFLPs was determined by the Dice coefficient. ${ }^{27}$

\section{Results}

\section{CHEF RFLP banding patterns}

SmaI digestion of the DNA of the 26 MRSA produced from 13-17 bands ranging from 7 to $700 \mathrm{~kb}$. The conditions required to obtain separation of the large bands (fig. 1) did not always enable the bands of $<20 \mathrm{~kb}$ to be visualised on the same gel. Electrophoresis conditions that enabled bands below $20 \mathrm{~kb}$ to be visualised showed that all isolates consistently had three bands of the same size which were $<20 \mathrm{~kb}$ (photographic data not shown). However, these bands are represented in fig. 2. Based on the summation of the bands, the average genome size for the isolates was c. $2800 \mathrm{~kb}$.

The banding patterns of the isolates enabled them to be classified into 17 different groups (fig. 2). The most prevalent pattern was that of group S7. Isolates producing this pattern were found in four different hospitals in four states; one isolate from each of Adel, Bris and Syd-1, and two isolates from Melb-1. The next most prevalent group was S2. It was found in isolates from three hospitals in three states; there were two isolates from Melb-2, two from Bris and one from Syd-2. There were only two isolates that gave a pattern represented by group $\mathrm{S13}$; one was from Adel and the other from Bris. Each of the other groups was represented by only one isolate.

It is interesting that there was no evidence that a particular type was prevalent in any one hospital. In some cases the groups were quite different and percentage similarity was as low as $62 \%$, e.g., S4 with S15 (table). In other cases, there was only a single band difference between groups, e.g., S13 and S16 (table). These small differences appear to be reliable as the method appeared to be very reproducible. Three isolates were chosen for repeat tests and, when the same preparation for each isolate was electrophoresed on different gels, the same results were obtained each 


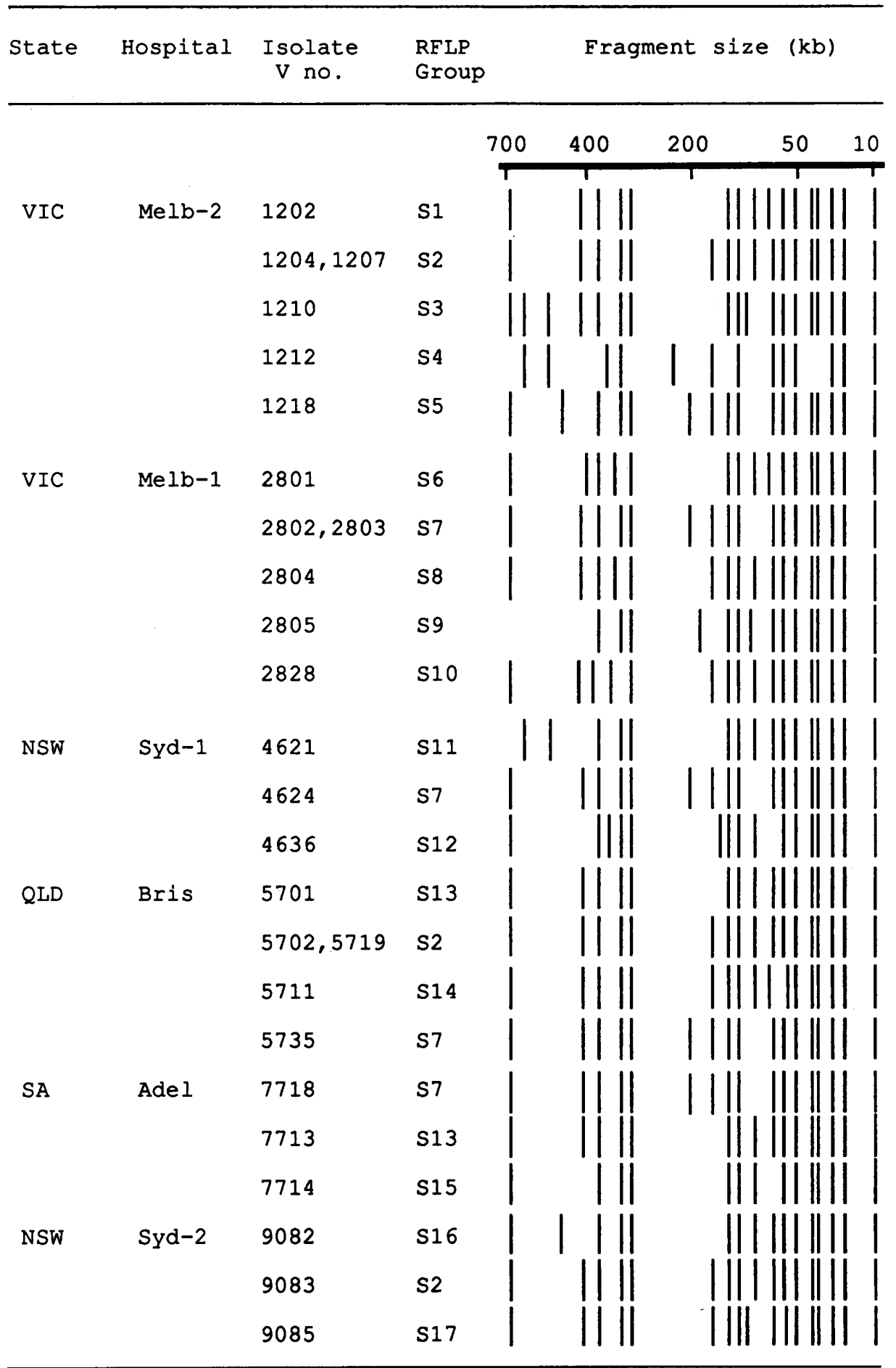

Fig. 2. Stylised RFLP patterns of Smal digested chromosomes of MRSA.

time. Additionally, when different inserts of different preparations were electrophoresed on the same gel the same result was again obtained for each isolate.

\section{Discussion}

Restriction endonuclease digestion analysis of DNA has been used to compare MRSA isolates. ${ }^{13,14}$ However, shearing of the DNA during preparation and the high frequency cutting enzymes used have produced numerous bands which have been difficult to interpret. Shearing has been overcome by lysing the cells and digesting the DNA in agarose blocks and the number of bands has been kept to an easily readable number by digesting with the low frequency cutting restriction endonuclease SmaI.

CHEF electrophoresis has enabled fragments from c. $10 \mathrm{~kb}$ to $700 \mathrm{~kb}$ to be visualised on the same gel. The bands were easy to read (fig. 1) and the results were reproducible.

The isolates were readily placed into groups based on their banding patterns and their relatedness can be calculated by the Dice coefficient. ${ }^{27}$ These results indicate that the MRSA isolates in Australia at the time of this survey ${ }^{25}$ were not all the same. Studies on 
Table. Percentage similarity of isolates based on their RFLP patterns

\begin{tabular}{|c|c|c|c|c|c|c|c|c|c|c|c|c|c|c|c|c|c|c|c|c|c|c|c|c|c|c|c|}
\hline \multirow{2}{*}{ Hospital } & \multirow{2}{*}{$\begin{array}{c}\text { Isolate } \\
\text { no. }\end{array}$} & \multirow{2}{*}{$\begin{array}{c}\text { RFLP } \\
\text { pattern }\end{array}$} & \multicolumn{25}{|c|}{ RFLP pattern } \\
\hline & & & S1 & $\mathbf{S 2}$ & S2 & S3 & S4 & S5 & S6 & S7 & S7 & S8 & S9 & S10s & S11 & S7 S & $\mathrm{S} 12$ & S13 & S2 & S14 & $\mathrm{S} 2$ & S7 S & $\mathrm{S} 13$ & S15 & S7 & S16 & S2 \\
\hline Syd-2 & $\begin{array}{l}9085 \\
9083 \\
9082\end{array}$ & $\begin{array}{l}\text { S17 } \\
\text { S2 } \\
\text { S16 }\end{array}$ & $\begin{array}{l}85 \\
97 \\
88\end{array}$ & $\begin{array}{r}94 \\
100 \\
91\end{array}$ & $\begin{array}{r}94 \\
100 \\
91\end{array}$ & $\begin{array}{l}91 \\
91 \\
88\end{array}$ & $\begin{array}{l}69 \\
71 \\
66\end{array}$ & $\begin{array}{l}88 \\
88 \\
91\end{array}$ & $\begin{array}{l}75 \\
85 \\
81\end{array}$ & $\begin{array}{l}94 \\
94 \\
82\end{array}$ & $\begin{array}{l}94 \\
94 \\
82\end{array}$ & $\begin{array}{l}88 \\
88 \\
85\end{array}$ & $\begin{array}{l}79 \\
79 \\
81\end{array}$ & $\begin{array}{l}82 \\
88 \\
77\end{array}$ & $\begin{array}{l}79 \\
85 \\
88\end{array}$ & $\begin{array}{l}94 \\
94 \\
85\end{array}$ & $\begin{array}{l}79 \\
79 \\
81\end{array}$ & $\begin{array}{l}91 \\
94 \\
94\end{array}$ & $\begin{array}{r}94 \\
100 \\
88\end{array}$ & $\begin{array}{l}88 \\
94 \\
85\end{array}$ & $\begin{array}{r}94 \\
100 \\
88\end{array}$ & $\begin{array}{l}94 \\
94 \\
85\end{array}$ & $\begin{array}{l}91 \\
97 \\
94\end{array}$ & $\begin{array}{l}84 \\
90 \\
93\end{array}$ & $\begin{array}{l}91 \\
97 \\
94\end{array}$ & $\begin{array}{l}85 \\
91\end{array}$ & 94 \\
\hline Adel & $\begin{array}{l}7718 \\
7714 \\
7713\end{array}$ & $\begin{array}{l}\text { S7 } \\
\text { S15 } \\
\text { S13 }\end{array}$ & $\begin{array}{l}94 \\
94 \\
94\end{array}$ & $\begin{array}{l}97 \\
90 \\
97\end{array}$ & $\begin{array}{l}97 \\
90 \\
97\end{array}$ & $\begin{array}{l}94 \\
80 \\
94\end{array}$ & $\begin{array}{l}65 \\
62 \\
65\end{array}$ & $\begin{array}{l}85 \\
84 \\
85\end{array}$ & $\begin{array}{l}81 \\
80 \\
81\end{array}$ & $\begin{array}{r}100 \\
84 \\
91\end{array}$ & $\begin{array}{r}100 \\
84 \\
91\end{array}$ & $\begin{array}{l}91 \\
71 \\
91\end{array}$ & $\begin{array}{l}81 \\
80 \\
81\end{array}$ & $\begin{array}{l}85 \\
77 \\
85\end{array}$ & $\begin{array}{l}88 \\
87 \\
88\end{array}$ & $\begin{array}{r}100 \\
84 \\
91\end{array}$ & $\begin{array}{l}81 \\
87 \\
81\end{array}$ & $\begin{array}{r}88 \\
93 \\
100\end{array}$ & $\begin{array}{l}97 \\
84 \\
97\end{array}$ & $\begin{array}{l}91 \\
84 \\
91\end{array}$ & $\begin{array}{l}97 \\
84 \\
97\end{array}$ & $\begin{array}{r}100 \\
84 \\
91\end{array}$ & $\begin{array}{l}91 \\
93\end{array}$ & 93 & & & \\
\hline Bris & $\begin{array}{l}5735 \\
5719 \\
5711 \\
5702 \\
5701\end{array}$ & $\begin{array}{l}\text { S7 } \\
\text { S2 } \\
\text { S14 } \\
\text { S2 } \\
\text { S13 }\end{array}$ & $\begin{array}{l}85 \\
91 \\
97 \\
91 \\
94\end{array}$ & $\begin{array}{r}94 \\
100 \\
94 \\
100 \\
97\end{array}$ & $\begin{array}{r}94 \\
100 \\
94 \\
100 \\
97\end{array}$ & $\begin{array}{l}91 \\
91 \\
85 \\
91 \\
94\end{array}$ & $\begin{array}{l}71 \\
69 \\
63 \\
69 \\
65\end{array}$ & $\begin{array}{l}94 \\
88 \\
82 \\
88 \\
85\end{array}$ & $\begin{array}{l}79 \\
79 \\
85 \\
79 \\
81\end{array}$ & $\begin{array}{r}100 \\
97 \\
88 \\
97 \\
91\end{array}$ & $\begin{array}{r}100 \\
97 \\
88 \\
97 \\
91\end{array}$ & $\begin{array}{l}88 \\
97 \\
94 \\
97 \\
91\end{array}$ & $\begin{array}{l}79 \\
79 \\
79 \\
79 \\
81\end{array}$ & $\begin{array}{l}72 \\
88 \\
88 \\
88 \\
85\end{array}$ & $\begin{array}{l}79 \\
79 \\
79 \\
79 \\
88\end{array}$ & $\begin{array}{r}100 \\
97 \\
88 \\
97 \\
91\end{array}$ & $\begin{array}{l}75 \\
79 \\
79 \\
79 \\
81\end{array}$ & $\begin{array}{l}91 \\
97 \\
91 \\
97\end{array}$ & $\begin{array}{r}97 \\
100 \\
94\end{array}$ & $\begin{array}{l}88 \\
94\end{array}$ & 97 & & & & & & \\
\hline Syd-1 & $\begin{array}{l}4636 \\
4624 \\
4621\end{array}$ & $\begin{array}{l}\text { S12 } \\
\text { S7 } \\
\text { S11 }\end{array}$ & $\begin{array}{l}75 \\
85 \\
81\end{array}$ & $\begin{array}{l}85 \\
94 \\
85\end{array}$ & $\begin{array}{l}85 \\
94 \\
85\end{array}$ & $\begin{array}{l}81 \\
91 \\
81\end{array}$ & $\begin{array}{l}71 \\
71 \\
77\end{array}$ & $\begin{array}{l}73 \\
94 \\
79\end{array}$ & $\begin{array}{l}75 \\
79 \\
75\end{array}$ & $\begin{array}{r}73 \\
100 \\
79\end{array}$ & $\begin{array}{r}73 \\
100 \\
79\end{array}$ & $\begin{array}{l}73 \\
88 \\
79\end{array}$ & $\begin{array}{l}69 \\
79 \\
81\end{array}$ & $\begin{array}{l}73 \\
72 \\
73\end{array}$ & $\begin{array}{l}81 \\
79\end{array}$ & 73 & & & & & & & & & & & \\
\hline Melb-1 & $\begin{array}{l}2828 \\
2805 \\
2804 \\
2803 \\
2802 \\
2801\end{array}$ & $\begin{array}{l}\text { S10 } \\
\text { S9 } \\
\text { S8 } \\
\text { S7 } \\
\text { S7 } \\
\text { S6 }\end{array}$ & $\begin{array}{l}79 \\
75 \\
85 \\
85 \\
85 \\
81\end{array}$ & $\begin{array}{l}88 \\
79 \\
94 \\
94 \\
94 \\
79\end{array}$ & $\begin{array}{l}88 \\
79 \\
94 \\
94 \\
94 \\
79\end{array}$ & $\begin{array}{l}73 \\
81 \\
85 \\
91 \\
91 \\
82\end{array}$ & $\begin{array}{l}71 \\
65 \\
69 \\
71 \\
71 \\
65\end{array}$ & $\begin{array}{l}82 \\
79 \\
82 \\
94 \\
94 \\
73\end{array}$ & $\begin{array}{l}85 \\
75 \\
79 \\
79 \\
79\end{array}$ & $\begin{array}{r}88 \\
79 \\
88 \\
100\end{array}$ & $\begin{array}{l}88 \\
79 \\
88\end{array}$ & $\begin{array}{l}88 \\
73\end{array}$ & 73 & & & & & & & & & & & & & & \\
\hline Melb-2 & $\begin{array}{l}1218 \\
1212 \\
1210 \\
1207 \\
1204 \\
1202\end{array}$ & $\begin{array}{l}\text { S5 } \\
\text { S4 } \\
\text { S3 } \\
\text { S2 } \\
\text { S2 } \\
\text { S1 }\end{array}$ & $\begin{array}{l}79 \\
65 \\
82 \\
91 \\
91\end{array}$ & $\begin{array}{r}88 \\
69 \\
86 \\
100\end{array}$ & $\begin{array}{l}88 \\
69 \\
86\end{array}$ & $\begin{array}{l}80 \\
65\end{array}$ & 69 & & & & & & & & & & & & & & & & & & & & \\
\hline
\end{tabular}

the EA MRSA ${ }^{8}$ of the early 1980s, based on the location of the resistance determinants and plasmid profiles, had indicated that the isolates were very similar and that a particular strain had spread around Australia. ${ }^{8-11}$ Although plasmid analysis has been very useful in typing MRSA, it does not reflect the overall genetic relatedness of isolates. Also, the relatedness of isolates can be obscured by the fact that plasmids can be lost or gained.

The advantage of the results reported here is that they reflect the overall relatedness of the complete bacterial genome. The results also indicate that the method could be useful in studying the epidemiology of MRSA within hospitals and between hospitals. It may enable the identification of strains which are more endemic or epidemic and should provide a means of studying the evolution of MRSA in Australia. It is clear that MRSA continues to be a problem in Australian hospitals ${ }^{25}$ so long after the epidemic of the gentamicin-resistant strain $^{5}$ of the early 1980s. It will be interesting to use CHEF electrophoresis to compare the isolates studied here with the EA MRSA of the 1980 s and with future isolates.

The genome size of $c .2800 \mathrm{~kb}$ calculated from these results is slightly larger than that reported in one study ${ }^{28}$ but close to the sizes of $2860^{29}$ and $2748^{30}$ reported by others.

This work was funded in part by grants to WBG from Markalinga Management (Western Diagnostic Services) and the National Health and Medical Research Council of Australia. M-QW was the recipient of grants from the Australia-China Council, the Cohen Fellowship, Beechman Australia Pty Ltd and Essex Asia Limited. We thank Miss Alison Vickery and the NSSG for providing the isolates. The NSSG was funded by Eli Lilly Australia.

\section{References}

1. Lane WR. Methicillin resistance in staphylococci. Med J Aust $1962 ; 49$ : 962-965.

2. Rountree PM, Beard MA. Hospital strains of Staphylococcus aureus, with particular reference to methicillin-resistant strains. Med J Aust 1968; 2: 1163-1168.

3. Rountree PM. History of staphylococcal infection in Australia. Med J Aust 1978; 2: 543-546.

4. Perceval A, McLean AJ, Wellington CV. Emergence of gentamicin resistance in Staphylococcus aureus. Med J Aust 1976; 2 : 74

5. Pavillard R, Harvey K, Douglas D et al. Epidemic of hospitalacquired infection due to methicillin-resistant Staphylo- coccus aureus, in major Victorian hospitals. Med $J$ Aust $1982 ; 1: 451-454$.

6. Lacey RW. Antibiotic resistance in Staphylococcus aureus and streptococci. Br Med Bull 1984; 40: 77-83.

7. McDonald PJ. Methicillin-resistant staphylococci : a sign of the times? Med J Aust 1982; 1: 445-446.

8. Townsend DE, Ashdown N, Pearman JW, Annear DI, Grubb WB. Genetics and epidemiology of methicillin-resistant Staphylococcus aureus isolated in a Western Australian hospital. Med J Aust 1985; 142: 108-111.

9. Grubb WB, Townsend DE, Greed LC, Ashdown N, Momoh M. Characteristics of methicillin-resistant Staphylococcus aureus epidemic in Australian hospitals. In : Spitzy KH, Karrer K (eds) Proceedings of the 13th international 
congress of chemotherapy. Vienna, Verlag H. Egermann. 1983; Part 83: 23-26.

10. Townsend DE, Grubb WB, Ashdown N. Genetics of drug resistance in methicillin-resistant Staphylococcus aureus from Australian hospitals. $J$ Hosp Infect 1983 ; 4: 331-337.

11. Lyon BR, Iuorio JL, May JW, Skurray RA. Molecular epidemiology of multiresistant Staphylococcus aureus in Australian hospitals. J Med Microbiol 1984; 17: 79-89.

12. Beard-Pegler MA, Vickery AM. Lysogenicity of methicillinresistant strains of Staphylococcus aureus. J Med Microbiol $1985 ; 20: 147-155$.

13. Jordens JZ, Hall LMC. Characterisation of methicillin-resistant Staphylococcus aureus isolates by restriction endonuclease digestion of chromosomal DNA. J Med Microbiol 1988; 27: 117-123.

14. Burnie JP, Matthews RC, Lee W, Murdoch D. A comparison of immunoblot and DNA restriction patterns in characterising methicillin-resistant isolates of Staphylococcus aureus. J Med Microbiol 1989; 29: 255-261.

15. Schwartz DC, Cantor CR. Separation of yeast chromosomesized DNAs by pulsed field gradient gel electrophoresis. Cell 1984; 37: 67-75.

16. Vollrath D, Davis RW. Resolution of DNA molecules greater than 5 megabases by contour-clamped homogeneous electric fields. Nucleic Acids Res 1987; 15: 7865-7876.

17. Carle GF, Frank M, Olson MV. Electrophoretic separations of large DNA molecules by periodic inversion of the electric field. Science 1986; 232 : 65-68.

18. Fan JB, Chikashige Y, Smith CL, Niwa O, Yanagida M, Cantor CR. Construction of a Not I restriction map of the fission yeast Schizosaccharomyces pombe genome. Nucleic Acids Res 1988; 17: 2801-2818.

19. Orbach MJ, Vollrath D, Davis RW, Yanofsky C. An electrophoretic karyotype of Neurospora crassa. Mol Cell Biol 1988; 8: 1469-1473
20. Smith CL, Klco S, Cantor CR. Pulsed-field gel electrophoresis and the technology of large DNA molecules. In: Davies KE (ed) Genome analysis: a practical approach. Oxford IRL Press. 1988: 41-72.

21. Smith CL, Econome JG, Schutt A, Klco S, Cantor CR. A physical map of the Escherichia coli K12 genome. Science 1987; 236: 1448-1453.

22. Kauc L, Mitchell M, Goodgal SH. Size and physical map of the chromosome of Haemophilus influenzae. J Bacteriol 1989; 171: 2474-2479.

23. Grothues D, Tümmler B. Genome analysis of Pseudomonas aeruginosa by field inversion gel electrophoresis. FEMS Microbiol Lett 1987; 48: 419-422.

24. Goering RV, Duensing TD. Rapid field inversion gel electrophoresis in combination with an rRNA gene probe in the epidemiological evaluation of staphylococci. J Clin Microbiol 1990; 28 : 426-429.

25. Turnidge J, Lawson P, Munro R, Benn R. A national survey of antimicrobial resistance in Staphylococcus aureus in Australian teaching hospitals. Med J Aust 1989; 150: 69-72.

26. Wei M-Q, Wang F, Grubb WB. Use of contour-clamped homogeneous electric field electrophoresis to type methicillin-resistant Staphylococcus aureus. J Med Microbiol $1992 ; 36$ : 172-176.

27. Dice LR. Measures of the amount of ecological association between species. Ecology 1945; 26: 297-302.

28. McClelland $\mathbf{M}$, Jones $R$, Patel $Y$, Nelson $M$. Restriction endonucleases for pulsed field mapping of bacterial genomes. Nucleic Acids Res 1987; 15: 5985-6005.

29. Weil MD, McClelland M. Enzymatic cleavage of a bacterial genome at a 10-base-pair recognition site. Proc Natl Acad Sci USA 1989; 86: 51-55.

30. Patel AH, Foster TJ, Pattee PA. Physical and genetic mapping of the protein A gene in the chromosome of Staphylococcus aureus 8325-4. J Gen Microbiol 1989; 135: 1799-1807. 